\title{
RESENHA DO LIVRO: Um país chamado favela: a maior pesquisa já feita sobre favela brasileira. MEIRELLES, Renato \& ATHAYDE, Celso. São Paulo: Edita Gente, 2014.
}

\section{Ana Patrícia Barbosa ${ }^{1}$}

O livro escrito por Renato Meirelles e Celso Athayde é resultado de uma ampla pesquisa denominada "Radiografias das Favelas Brasileiras", realizada pelo Instituto Data Favela e coordenada pelos próprios autores, com o objetivo de mapear a realidade das favelas brasileiras. Em linhas gerais, o livro apresenta um balanço crítico sobre as experiências de Meirelles e Athayde em 63 favelas de 35 cidades brasileiras, onde foram ouvidas 2.000 pessoas ao longo do ano de 2013, associando dados estatísticos com histórias de quem vive o cotidiano da favela.

O prefácio do livro é de autoria do sociólogo Luiz Eduardo Soares, que atribui à obra de Meirelles e Athayde, por seu alcance e por sua originalidade, uma referência incontornável, que inaugura um novo momento, de maturidade, de abertura, de liberdade crítica para escrever sobre a História de nosso país e que permite um olhar de dentro para fora da favela.

Ao longo dos sete capítulos que estruturam o livro os autores desmistificam a ideia de um território de pobreza e miséria que não representa as favelas brasileiras. Pelo contrário, a realidade apresentada por Meirelles e Athayde é de uma população de 11,7 milhões de habitantes, que vive em favelas, o que equivale a $6 \%$ da população brasileira e que se comprado a um estado, seria o quinto mais populoso, capaz de movimentar 63 bilhões de reais ao ano.

A característica empreendedora dos moradores de favelas é tratada pelos autores como algo que passou a ser ainda mais notável nos últimos 10 anos como decorrência de um certa ascensão social. O estudo realizado em 2013 revela que o ritmo de avanço nas favelas é mais acelerado do que no Brasil em geral. As favelas têm mais moradores de classe média (65\%) do que o Brasil como um todo (54\%), sendo que a média salarial das pessoas que moram nas favelas cresceu 54,7\% de 2003 a 2013 e no Brasil o crescimento neste mesmo período foi de $37,9 \%$. Poucas pessoas atribuem esse avanço

\footnotetext{
${ }^{1}$ Universidade Feevale, Brasil.
} 
às políticas públicas ou aos empregadores. Para a maioria dos moradores das favelas, a ascensão social está associada, principalmente ao resultado do esforço pessoal.

Durante todo o livro, Meirelles e Athayde abordam a ascensão social do povo da favela e reforçam a importância desses indivíduos para o Brasil. São estes personagens, invisíveis aos olhos da mídia, aos intelectuais e à grande parte dos planejadores de negócios, que contribuem para girar a roda da economia do país. Um contingente de pessoas que constituem novos padrões de consumo, que reinventam atividades econômicas e que contribuem decisivamente para definir o perfil cultural do país dos emergentes. Pessoas como o próprio Athayde (um dos autores do livro). Sua história é narrada por Meirelles. Segundo ele, Athayde não aprendeu com Keynes ou com Amartya Sen, mas sim com a vida, tocando pequenos negócios no vasto universo dos excluídos. Nasceu na Baixada Fluminense, no Rio de Janeiro, morou nas ruas, sobrevivendo de caridade e venda de doces, viveu por dois anos em um abrigo público e depois foi ocupar um pedaço de chão da Favela do Sapo. Com o tempo considerou que podia ganhar a vida como camelô. Desde então passou por diversos ramos, até, em 2013, criar a primeira holding do Brasil fixada nas favelas, a Holding Brasil.

Porém, histórias como essas não são retratadas com destaque pela mídia. A preocupação volta-se para retratar as favelas a partir de um estereótipo midiático, que delimitou um lugar para as pessoas que ali vivem: o de miseráveis, incultos, indolentes e bárbaros. Existe uma favela real, de madeira, ferro, cimento, carne e osso, mas a outra ficcional, da prosa de invenção, constituída sob encomenda para legendar os rótulos de desaprovação colados sobre os excluídos. A favela de verdade apresenta-se na diversidade, plena de defeitos e virtudes. Aquela imaginada no asfalto, porém, é apenas reduto do vício e da perversão, que se difundiu massivamente durante décadas, conforme o receituário de estigmatização do conjunto de pês: pretos, pobres e proletários privados de propriedade.

$\mathrm{Na}$ busca por desmistificar este lugar, Um país chamado favela, documenta o que a mídia não registra: sonhos, desejos, dramas, conflitos, histórias de integração cotidiana de pessoas como Athayde, que (re)configuram suas identidades e pertencimentos construindo inúmeras formas de sobrevivência num território permeado pela fragmentação de ações e serviços dada a ausência de investimentos por parte do Estado. Ausência essa apontada por MV Bill na apresentação da obra: "a favela é o lugar onde o Estado não se instalou de fato (nem por isso deve ser associada a carência, 
pois esta existe em todas as classes), mas é o lugar em que precisa ser ativada a qualidade de todos os serviços públicos para evitar o medo, a escuridão, o lixo largado, a insegurança, a ilegalidade".

A importância do trabalho de Meirelles e Athayde reside nas muitas histórias dos moradores das favelas, pessoas felizes, que gostam e tem cada vez mais orgulho do lugar onde moram e que não estão dispostos a abandoná-lo. Se existe amor e fidelidade ao lugar, a principal razão são os laços de solidariedade entre os moradores. Assim, a favela se torna não somente espaço físico, mas código de relações de convívio, onde as pessoas constroem alianças de solidariedade, tendo quase sempre com quem contar. São elos de solidariedade, que contam a favela um grau de tantas peculiaridades, onde a população cria estratégias para subsistir no vácuo deixado pelo Estado.

Nessas histórias narradas, Meirelles e Athayde se depararam com cenários heterogêneos. Ao mesmo tempo em que viram grandes avanços, comércios desenvolvidos, casas de alvenaria, viram também graves problemas estruturais, casas em área de risco, de difícil acesso, em que se equilibram humildes barracos de madeira. Pessoas passando dificuldades para sustentar suas famílias, ou aflitas pela falta de serviços de saúde, como também festejando o ingresso na universidade, ou a construção de mais um andar da sua casa. O retrato da realidade de um país, tanto no morro, quanto no asfalto, que independentemente do formato, está presente m qualquer grande cidade.

Assim, Um país chamado favela compreende uma série de estudos sobre favelas brasileiras, mas, antes de tudo, o faz a partir de seus habitantes, narradores reais, que contam suas próprias histórias, como a de Marivaldo, que mora no Complexo do Alemão junto com sua família, numa casa simples, como tantas outras de brasileiros que ascenderam à classe média. Marivaldo conta que nasceu em Nova Brasília, núcleo vizinho ao Alemão, em uma família que superou as dificuldades: "minha mãe deu duro para sustentar os filhos e se esforçou para colocar todos eles no bom caminho”. Fala também que a vida no Alemão nem sempre foi como está hoje e define como principal mudança a econômica. Segundo ele, as comunidades são menos pobres do que nos anos 1980, quando gastou a juventude à procura de um meio honesto de sobrevivência. Hoje Marivaldo divide-se entre a profissão de motorista e outra como técnico em eletrônica, especialista na montagem de bombas de combustível. 
A biografia de Marivaldo revela o que é natural, em qualquer tempo e lugar, que aqueles desprovidos de oportunidades, aqui e ali, recorrem mais frequentemente à atividade ilícita, muitas vezes último recurso garantidor da sobrevivência. Conforme análise apresenta por Meirelles e Athayde, qualquer estudo sociológico criterioso da vida nas grandes cidades confirma que o crime emerge da segregação e da supressão de direitos, nunca de uma inclinação natural de determinados indivíduos ou grupos étnicos.

Assim, Um país chamado favela, é permeado por histórias de personagens que se que se reinventam e ressignificam a favela, atribuindo-lhe vida e coração, que respira e é composto pela síntese de suas gentes. É neste território que se encontra o campo de possibilidades, o lugar para viver e prosperar, onde se (re)configuram identidades e pertencimentos e onde se forjam, dialeticamente, as resistências e lutas coletivas. Dizer que esta é uma obra para compreender as favelas do Brasil seria reduzi-la. Ao longo dos sete capítulos, somos conduzidos a compreender as transformações do país, a despeito de inúmeras pendências seculares no que tange à universalização de direitos.

Recebido em: 17/03/2015 Aprovado em: 09/06/2015 